\title{
Biochemical features of a Protoceratium reticulatum red tide in Chipana Bay (Northern Chile) in summer conditions
}

\author{
SERGIO ROSSI ${ }^{1}$ and IDA FIORILLO ${ }^{2}$ \\ ${ }^{1}$ Institut de Ciència i Tecnologia Ambientals, Universitat Autònoma de Barcelona, Campus Cn UAB s/n, \\ 08193 Cerdanyola del Vallés, Spain. E-mail: Sergio.Rossi@uab.cat \\ ${ }^{2}$ Instituto Ciencias del Mar (CSIC), Pg. Marítim de la Barceloneta 37-49, Barcelona 08003, Spain.
}

SUMMARY: Protoceratium reticulatum is considered a potential toxic dinoflagellate. This paper describes a high-frequency monitoring study performed at Chipana Bay (northern Chile), sampling over 48 hours in a near-bottom shallow coastal area to quantify the biochemical features of a red tide dominated by this microscopic algae. This area belongs to the Humboldt Current upwelling system, and is considered highly productive for artisanal fisheries. Total chlorophyll $a$, total lipids, particulate organic carbon and nitrogen, fatty acids and major phytoplankton group concentration (i.e. dinoflagellates, diatoms, ciliates and cysts) were studied in 7-hour intervals in February 2007. Our results indicate a high concentration of potential available food in the form of lipids ranging from 50 to $300 \mu \mathrm{g} \mathrm{L}^{-1}$ for benthic suspension feeders, i.e. bivalves. The dominance of $P$. reticulatum $\left(60-80 \%\right.$ of the total cell concentration per litre, ranging from $55 \times 10^{3}$ to $384 \times 10^{3}$ cells $\left.\mathrm{L}^{-1}\right)$ can be considered as a possible interference for harvesting in this productive area, although the toxicity of this algae was not proved in the present study. The main dinoflagellate fatty acid markers $[18: 0,18: 4(n-3), 20: 5(n-3)$, and 22:6(n-3)] showed high proportions $(\%)$ during the short time cycle and in at least two cases [the 18:4 (n-3) and 22:6 (n-3) fatty acids] a highly significant relationship with dinoflagellate concentration (cells $\mathrm{L}^{-1}$ ). The topographical and benthic structure (mainly kelp forest) of the zone helps to retain particles and nutrients that may in part explain the high productivity and food availability, but the presence of recurrent red tides in this coastal area-if they prove to be toxic_is argued to be a major problem for local fisheries.

Keywords: Protoceratium reticulatum, red tide, available food, dinoflagellate, fatty acids, upwelling system.

RESUMEN: CARACTERÍsticas BIOQuímiCAS DE UNA MAREA ROJA DE PRotoceratium RETICULATUM EN LA BAHÍA DE CHIPANA (Norte De Chile) En CONDiCiOnes estivales. - Protoceratium reticulatum es un dinoflagelado considerado potencialmente tóxico. En el presente estudio se realizaron una serie de muestreos con elevada frecuencia en la bahía de Chipana (norte de Chile), recolectando diferentes parámetros durante 48 horas en aguas cercanas al fondo en un área costera de poca profundidad para cuantificar las características bioquímicas de una marea roja dominada por esta alga microscópica. El área de estudio pertenece al sistema de surgencia de la corriente de Humboldt y es considerada muy productiva especialmente para la pesca de tipo artesanal. Se estudiaron la concentración de clorofila $a$, los lípidos totales, el carbono y nitrógeno particulados y los ácidos grasos del seston en suspensión, así como los principales grupos unicelulares (dinoflagelados, diatomeas, ciliados y cistes) mediante recuento celular cada siete horas en el periodo estival (febrero 2007). Los presentes resultados muestran una elevada cantidad de alimento potencial disponible (en forma de lípidos, con un rango de 50 a $300 \mu \mathrm{g} \mathrm{L}{ }^{-1}$ ) para los suspensívoros bentónicos, i.e. bivalvos. Pero el dominio de P.reticulatum (60-80\% del total de células observadas, con un rango de $55 \times 10^{3}$ a $384 \times 10^{3}$ células $\mathrm{L}^{-1}$ ) puede considerarse un factor de interferencia en la recolección de los moluscos en esta área productiva, aunque no hay prueba en el presente estudio de que la proliferación algal fuese tóxica. Los ácidos grasos de origen algal de tipo dinoflagelado [18:0, 18:4(n-3), 20:5(n-3), y 22:6(n-3)] mostraron elevadas proporciones (\%) durante el ciclo y al menos dos de ellos [los ácidos grasos 18:4 (n-3) y 22:6 (n-3)] mostraron una relación significativa con la concentración de dinoflagelados (células $\mathrm{L}^{-1}$ ). La topografía del fondo y la estructura de la comunidad bentónica (principalmente praderas de Kelp) en la zona de estudio pueden ayudar a retener partículas y nutrientes que pueden en parte explicar la elevada productividad y la disponibilidad de alimento, pero la presencia de mareas rojas recurrentes como la observada en el presente estudio, si demuestran ser tóxicas, puede llegar a ser un problema para la pesquería local.

Palabras clave: Protoceratium reticulatum, marea roja, alimento disponible, dinoflagelado, ácidos grasos, surgencia costera. 


\section{INTRODUCTION}

The upwelling area of northern Chile is one of the most productive systems around the world, supporting fisheries and aquaculture in both the pelagic and benthic zones (Escribano et al., 2004; González et al., 2004; Arntz et al., 2006). During the annual cycle, phytoplankton composition and productivity change in this area (González et al., 2004; Herrera and Escribano, 2006). Particulate organic matter availability for pelagic and benthic fauna may differ throughout the year (Aguilera et al., 2009), a factor which could be partly responsible for the population dynamics of secondary production in this highly productive zone (HernándezMiranda et al., 2003).

Red tides are common in these upwelling areas, especially on the coast and in summer conditions (Pitcher and Calder, 2000; Uribe and Espejo, 2003). In Chile and Perú, the coastal economy is based mostly on artisanal fisheries (Thatje et al., 2008), and red tides are a well known negative event for consumption of fish and shellfish that have accumulated phytoplankton toxins filtered from sea water (Masó and Garcés, 2006).

Red tides represent a serious potential risk for fish and shellfish production and, indirectly, for human health (Masó and Garcés, 2006). Phytoplankton proliferations have different impacts on benthic coastal populations depending mainly on cell concentration and algal species. Only 200 of the 4000 marine planktonic algae are considered harmful (Zingone and Enevoldsen, 2000), and some species may be harmful even at low concentrations $\left(10^{2}-10^{4}\right.$ cells $\left.\mathrm{L}^{-1}\right)$ in sea water (Reguera et al., 1993). Moderate-to-low concentrations of some dinoflagellates (e.g. Alexandrium catenella, Dinophysis acuta, Protoceratium reticulatum) are responsible for the accumulation of toxins that may be associated not only with the negative effects on fisheries (Sekiguchi et al., 2001), but on the physiology and production of shellfish ( $\mathrm{Li}$ et al., 2002). In particular, the dinoflagellate Protoceratium reticulatum contains high levels of yessotoxins (Satake et al., 1997; Paz et al., 2007), which may be highly toxic and have a long-term effect on shellfish populations (Fernández-Reiriz et al., 2008). The effectiveness of these molecules depends on the environmental conditions in which $P$. reticulatum grows (Guerrini et $a l ., 2007)$. Because the effect of toxins depends on the time of organism exposure to the red tide (Sekiguchi et al., 2001), a deeper knowledge of red tide dynamics is a main target to plan Harmful Algae Bloom (HAB) monitoring programmes. However, dinoflagellates are known to have high caloric value (Hithcock, 1982), and a red tide could be attractive for some suspension feeders, despite its potential toxicity (Fernández-Reiriz et al., 2008). Characterization of lipid contents and fatty acids profiles might help to determine the nutritional value of a specific algal proliferation.

To better understand coastal algal proliferations and their effects on shellfish and other organisms, short time cycle studies are needed. Environmental changes can take place rapidly in marine coastal systems, and the importance of short time-scale changes for understanding ecosystem variability has become evident (Taylor and Howes, 1994). Without such high-frequency sampling, production peaks in coastal ecosystems go undetected, and the final interpretation of the seasonal cycle may be flawed (Taylor and Howes, 1994; Rossi and Gili, 2007). In the study area, the phytoplankton monitoring is performed weekly, with some periods in which the effort is made every 2-3 days (FuentesGrünewald personal communication). The Bivalve Mollusc Sanitary Programme (PSMB) set up by the National Fishery Service (Sernapesca) of the Chilean Government established a monitoring programme in natural shellfish banks and aquaculture areas. When potentially toxic dinoflagellates reach detectable quantitative concentrations $\left(<10\right.$ cell $\left.\mathrm{mL}^{-1}\right)$, high-frequency monitoring (every 48 hours) is established. Changes within very short periods have been shown in coastal areas (few hours, Rossi and Gili, 2007) and high-frequency sampling during red tide conditions will help in the final interpretation of the HAB impact on coastal communities.

One of the objectives of the CENSOR European project, within which this study was carried out, is to provide tools for management, especially of small Chilean and Peruvian fishery enterprises that need more information about potential impacts on harvested organisms (bivalves, sea urchins and ascidians) of changes in food quality and quantity in the coastal water column. In this study, a Protoceratium reticulatum red tide progress was monitored for 48 hours in nearbottom coastal waters in the upwelling area of Iquique (northern Chilean coast) using a high-frequency sampling design. Several parameters were chosen to understand algal concentration changes and also the food availability (quality and quantity of particulate organic matter) for filter feeders, which are the main economic source for the people in this area (Thatje et al., 2008; Villegas et al., 2008). Several parameters were chosen to describe food availability changes associated with a red tide in an area where some benthic resources (bivalves, ascidians, sea urchins) are very abundant and actively fished. Biochemical parameters of surface coastal water samples (chlorophyll $a$, total lipids, particulate organic carbon and nitrogen concentrations and fatty acid composition) were monitored together and the main algal groups (the dinoflagellate $P$. reticulatum, other dinoflagellates, diatoms, etc.) were observed within a short-time cycle (48 hours each 7 hours) in summer conditions. This information could be very positive for artisanal coastal fisheries management.

\section{MATERIALS AND METHODS}

The study was carried out on the Chipana Coast $\left(21.32^{\circ} \mathrm{S}-70.07^{\circ} \mathrm{W}\right.$, northern Chile). The bay is situated $120 \mathrm{~km}$ south of Iquique, in one of the most productive 
TABLE 1. - Sampled variables and number of replicates made each time in the fixed point from 7:00 on 14 February 2007 to 7:00 on 16 February 2007.

\begin{tabular}{|c|c|c|c|c|c|c|}
\hline Day & Hour & Chlorophyll $a$ & Total Lipids & POC-PON & Phytoplankton groups & Fatty Acids \\
\hline $14 / 02 / 07$ & 7:00 & 3 & 3 & 1 & 3 & 3 \\
\hline $14 / 02 / 07$ & $14: 00$ & 3 & 3 & 1 & 3 & 2 \\
\hline $14 / 02 / 07$ & 21:00 & 3 & 3 & 1 & 3 & 3 \\
\hline $15 / 02 / 07$ & $7: 00$ & 3 & 3 & 1 & - & 3 \\
\hline $15 / 02 / 07$ & $14: 00$ & 3 & 3 & 1 & 3 & - \\
\hline $15 / 02 / 07$ & 21:00 & 3 & 3 & 1 & 3 & 3 \\
\hline $16 / 02 / 07$ & $7: 00$ & 3 & 3 & 1 & 3 & 3 \\
\hline
\end{tabular}

areas of the Humboldt Current system. It faces north, and hosts a small village that is subject to little anthropogenic influence. Ten kilometres South of Chipana is the Loa River discharge, which has no influence on the bay except during El Niño events, when the discharge increases due to intense precipitation (Palma et al., 2006). This zone has been described as a highly productive area (Herrera and Escribano, 2006) and a spawning site for small pelagic fishes (Herrera and Escribano, 2006; Palma et al., 2006). Near the coast the nutrient and organic material and the density and biomass of sandy-muddy bottom organisms may be considered high (Quiroga et al., 2005). This coastal system holds a very rich benthic macraolgae community in the shallower area, and dense equinoderm, bivalve and gastropod populations that are intensively harvested (Villegas et al., 2008).

\section{Water sampling}

Sampling for biochemical characterization of seston composition was carried out from 14 to 16 February 2007 (Table 1). Seawater (22-24 L) was collected at 7:00, 14:00 and 21:00 on 14 and 15 February, and at 7:00 on 16 February. Samples were taken from the surface at a distance of 20 metres from the rocky coast, using $10 \mathrm{~L}$ PVC bottles (2-2.5 $\mathrm{m}$ above the benthic community, mainly sand and Macrocystis integriflora kelp). The PVC bottles were rinsed with deionized water after each use. The 10-L bottles were stored in ice $\left(6-10^{\circ} \mathrm{C}\right)$ until arrival at the laboratory on shore (maximum elapsed time between collection and arrival: 10 minutes). The sea water samples were preserved at $6-10^{\circ} \mathrm{C}$ in the dark until filtration (maximum 1 hour). The samples were pre-filtered through a $200-\mu \mathrm{m}$ mesh to quantify seston and avoid large particles and plankters (Rossi and Gili, 2007).

\section{Biochemical variables}

To determine the chlorophyll $a$ concentration, three $100-\mathrm{mL}$ replicates were filtered through $\mathrm{GF} / \mathrm{F}$ pre-combusted glass fibre filters and stored at $-20^{\circ} \mathrm{C}$ (Table 1). Chl $a$ was extracted in $8 \mathrm{~mL} \mathrm{90 \%} \mathrm{acetone} \mathrm{in} \mathrm{the} \mathrm{dark} \mathrm{at}$ $4^{\circ} \mathrm{C}$ for 24 hours. The supernatant was read in a Turner Design fluorometer following Parsons et al., (1985).

For the organic particulate carbon (POC) and particulate organic nitrogen $(\mathrm{PON}), 250 \mathrm{~mL}$ sea water was filtered in each sampling time through pre-combusted $\left(450^{\circ} \mathrm{C}, 5 \mathrm{~h}\right) \mathrm{GF} / \mathrm{F}$ filters and immediately frozen in liquid nitrogen (Table 1). Subsequently, the filters were dried at $60^{\circ} \mathrm{C}$ for $24 \mathrm{~h}$. The filters were left in an $\mathrm{HCl}-$ saturated atmosphere for $48 \mathrm{~h}$ to destroy any inorganic material (Rossi and Gili, 2005; Rossi and Gili, 2007). Another $24 \mathrm{~h}$ were necessary to completely dry the filters $\left(60^{\circ} \mathrm{C}\right)$ before analysis with the $\mathrm{C}: \mathrm{N}$ autoanalyzer (Perkin-Elmer 240).

For total lipids of the water column, $1500 \mathrm{~mL}$ X 3 replicates were filtered through pre-combusted $\left(450^{\circ} \mathrm{C}\right.$, $5 \mathrm{~h}) \mathrm{GF} / \mathrm{F}$ filters and immediately frozen in liquid nitrogen (Table 1). Subsequently, the filters were freezedried for $12 \mathrm{~h}$ and stored at $-20^{\circ} \mathrm{C}$ pending analysis. Total lipids were analyzed using Barnes and Blastock, (1973) spectrophotometrical procedure. Filters were extracted in chlorophorm-methanol $(2: 1 \mathrm{v} / \mathrm{v})$. The extract was dried, using sulphuric acid and vanilline to complete the colorimetric method. Blanks were made to control the interference of filter glass fibre particles and cholesterol was used as a standard (Grémare et al., 1997).

\section{Phytoplankton concentration}

To quantify phytoplankton, $150 \mathrm{ml}$ water samples of each sampled point were preserved with Lugol acid solution $(0,2 \%$ final concentration) (Table 1$)$. After 1 minute of gentle shaking, subsamples of $10 \mathrm{ml}$ were transferred to settling chambers according to the Utermöhl method (1958) and left at least 12 hours until counting. Phytoplanktonic cells were counted in the entire chamber using an inverted microscope. The major groups of phytoplankton (dinoflagellates, cysts of dinoflagellates, diatoms and ciliates) were quantified. Protoceratium reticulatum were counted separately, as was the dominant species. Within the group of diatoms, cells with a dimension (length or width) $>$ or $<50 \mu \mathrm{m}$ (using an ocular micrometer) were counted separately.

\section{Fatty acid analysis}

Water samples $(2 \times 1500 \mathrm{~mL}$, ) were filtered through Whatman GF/F pre-combusted glass fibre filters and immediately frozen in liquid $\mathrm{N}_{2}$ (Table 1 ). Subsequent$1 \mathrm{y}$, the filters were freeze-dried for $12 \mathrm{~h}$ and stored at $-20^{\circ} \mathrm{C}$ until analysis. Filters were placed in a tube with 3:1 DCM:MeOH (dichloromethane-methanol), spiked 
with an internal standard (2-octyldodecanoic acid and the $5 \beta$-cholanic acid) and extracted using microwave assisted extraction $\left(5 \mathrm{~min}\right.$. at $\left.70^{\circ} \mathrm{C}\right)$. After centrifugation the extract was taken to near dryness in a centrifugal vacuum concentrator at a constant temperature and fractionated by solid phase extraction according to Ruiz et al., (2004). The sample was redissolved in $0.5 \mathrm{~mL}$ of chloroform and eluted through a $500 \mathrm{mg}$ aminopropyl mini-column (Waters Sep-Pak ${ }^{\circledR}$ Cartridges) (previously activated with $4 \mathrm{~mL}$ of $n$-hexane). The first fraction was eluted with $3 \mathrm{~mL}$ chloroform:2-propanol (2:1) and the fatty acids recovered with $8.5 \mathrm{~mL}$ of diethyl ether:acetic acid (98:2). Despite reported concerns on the background levels of aminopropyl columns (Russell and Werne, 2007), the SPE cartridges used had concentrations of target FFA below the detection limit. The FFA fraction was methylated using a solution of $20 \% \mathrm{MeOH} /$ $\mathrm{BF}_{3}$ heated at $90^{\circ} \mathrm{C}$ for $1 \mathrm{~h}$. The reaction was quenched with $4 \mathrm{~mL}$ of water saturated with $\mathrm{NaCl}$. The methyl esters of FFA were recovered by extracting twice with $3 \mathrm{~mL}$ of $n$-hexane. The combined extracts were taken to near dryness, re-dissolved with $1.5 \mathrm{~mL}$ of chloroform and eluted through a glass column filled with $\mathrm{Na}_{2} \mathrm{SO}_{4}$ to remove residual water; after removal of the chloroform with nitrogen, the extracted sample was stored at $-20^{\circ} \mathrm{C}$ until analysis by gas chromatography (GC). Chromatographic analysis extracts were redissolved in $30 \mu \mathrm{L}$ of isooctane. GC analysis was performed in a Thermo Finnigan Trace GC ultra instrument equipped with a flame ionization detector, a splitless injector and a DB-5 Agilent column ( $30 \mathrm{~m}$ length, $0.25 \mathrm{~mm}$ internal diameter and $0.25 \mu \mathrm{m}$ phase thickness). Helium was used as a carrier gas at $33 \mathrm{~cm} \mathrm{~s}^{-1}$. The oven temperature was programmed to increase from $50^{\circ} \mathrm{C}$ to $320^{\circ} \mathrm{C}$ at $10^{\circ} \mathrm{C}$ $\mathrm{min}^{-1}$. Injector and detector temperatures were $300^{\circ} \mathrm{C}$ and $320^{\circ} \mathrm{C}$, respectively. Methyl esters of fatty acids were identified by comparing their retention times with those of standard fatty acids (37 FAME compounds, Supelco® Mix C4-C24). Fatty acids were quantified by integrating areas under peaks in the gas chromatograph traces (Chromquest 4.1 software), with calibrations derived from internal standards.

\section{Statistics}

Biochemical parameters (chlorophyll, particulate organic carbon and lipid concentrations) and the proportions of the main groups of phytoplankton (Dinoflagellates and Diatoms) and fatty acid trophic markers were fitted using the STATISTICA 6.0 software package.

\section{RESULTS}

\section{Biochemical variables}

Chlorophyll $a$ showed a concentration peak on the first afternoon of intensive sampling (14:00 on 14 February, Fig. 1). The concentration was almost constant

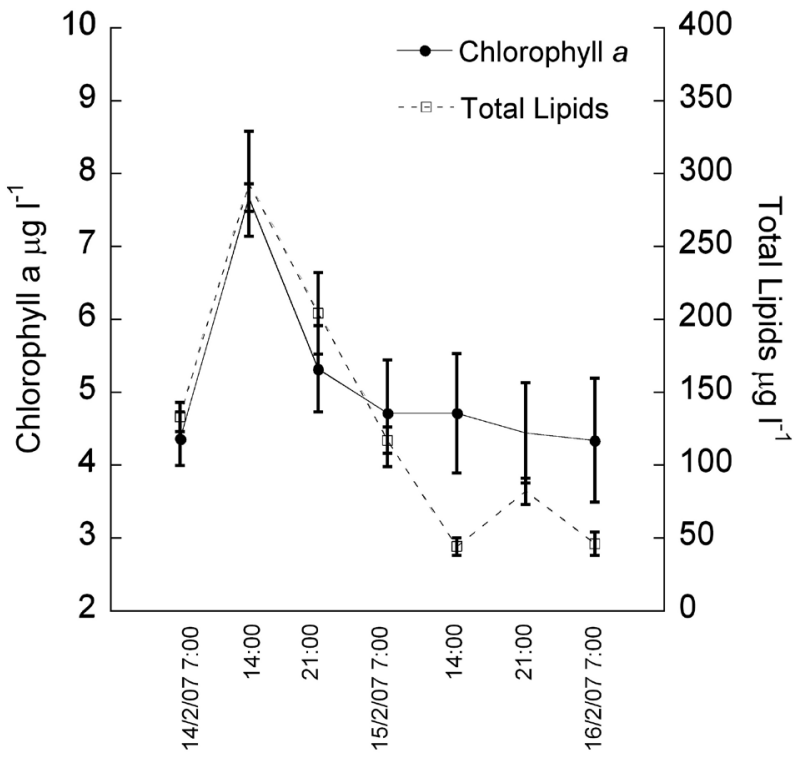

FIG. 1. - Chlorophyll $a$ and total lipids ( $\left.\mu \mathrm{L} \mathrm{L}^{-1}\right)$ during the 48-hour cycle at Chipana Bay.

during the overall period of sampling (between 4 and 5 $\left.\mu \mathrm{g} \mathrm{Chl} a \mathrm{~L}^{-1}\right)$ in the coastal zone studied, except at this moment (14:00), when the Chl $a$ concentration doubled its value (reaching almost $8 \mu \mathrm{g} \mathrm{Chl} a \mathrm{~L}^{-1}$ ). There was also a sudden lipid concentration peak at 14:00 on 14 February (Fig. 1), with almost $300 \mu \mathrm{g} \mathrm{Lip} \mathrm{L} \mathrm{L}^{-1}$, but the decrease after the detected concentration peak was smoother compared to the chlorophyll $a$, reaching 50 $\mu \mathrm{g} \mathrm{L} \mathrm{L}^{-1}$ at the end of the cycle $\left(1 / 6^{\text {th }}\right.$ of the top value on the afternoon of 14 February).

Particulate organic carbon and nitrogen during this short time cycle is shown in Figure 2. The highest values were also reached at 14:00 on 14 February, with

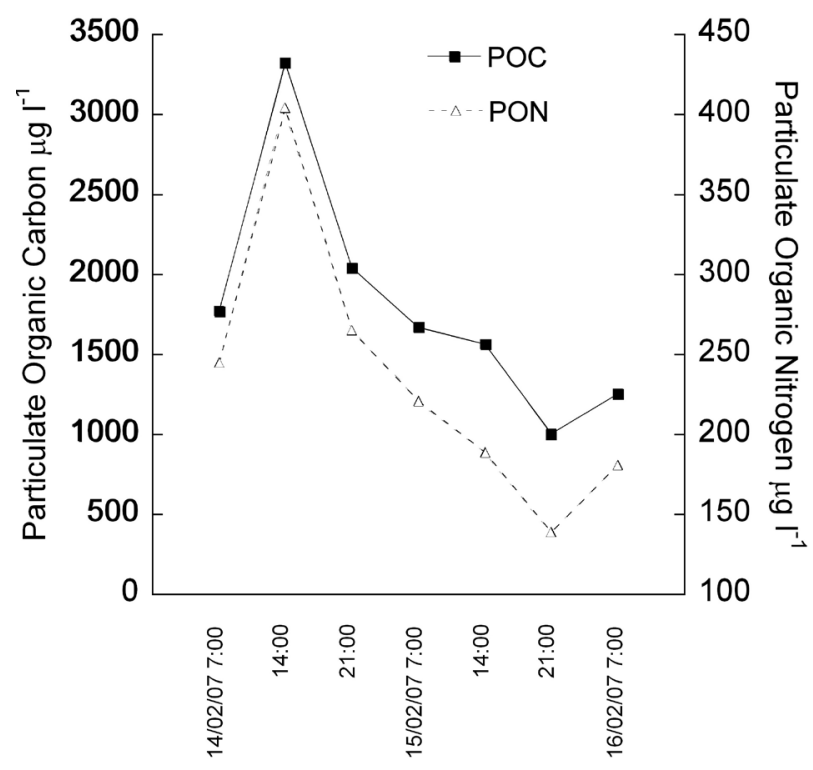

FIG. 2. - Particulate organic carbon (POC) and particulate organic nitrogen $(\mathrm{PON})\left(\mu \mathrm{g} \mathrm{L}^{-1}\right)$ during the 48-hour cycle at Chipana Bay. 
TABLE 2. - Main groups of phytoplankton in Chipana Bay during the short time cycle of 14-16 February 2007. For 15 February no sample is available. Diatoms above $50 \mu \mathrm{m}$ include diatom chains found in the present study.

\begin{tabular}{|c|c|c|c|c|c|c|c|c|c|}
\hline Day & Hour & $\begin{array}{l}\text { Protoceratium } \\
\text { reticulatum }\end{array}$ & $\begin{array}{c}\text { Other } \\
\text { dinoflagellates }\end{array}$ & Cysts & $\begin{array}{l}\text { Diatoms } \\
>50 \mu \mathrm{m}\end{array}$ & $\begin{array}{l}\text { Diatoms } \\
<50 \mu \mathrm{m}\end{array}$ & $\begin{array}{c}\text { Total } \\
\text { diatoms }\end{array}$ & Ciliates & $\begin{array}{c}\text { Total } \\
\text { Cells L-1 }\end{array}$ \\
\hline 14.02 .07 & 7:00 & 92680 & 12060 & 9480 & 2480 & 5360 & 7840 & 60 & 139440 \\
\hline 14.02 .07 & $14: 00$ & 383520 & 11040 & 28320 & 9520 & 17600 & 27120 & 320 & 505760 \\
\hline 14.02 .07 & 21:00 & 129200 & 12300 & 13200 & 4400 & 9100 & 13500 & 100 & 195000 \\
\hline 15.02 .07 & 7:00 & - & - & - & - & - & - & - & - \\
\hline 15.02 .07 & $14: 00$ & 54800 & 6800 & 14600 & 5700 & 15400 & 21100 & 200 & 133200 \\
\hline 15.02 .07 & 21:00 & 88200 & 18800 & 15600 & 4100 & 9700 & 13800 & 100 & 136500 \\
\hline 16.02 .07 & $7: 00$ & 125300 & 17700 & 16000 & 3100 & 4500 & 7600 & 100 & 146700 \\
\hline
\end{tabular}
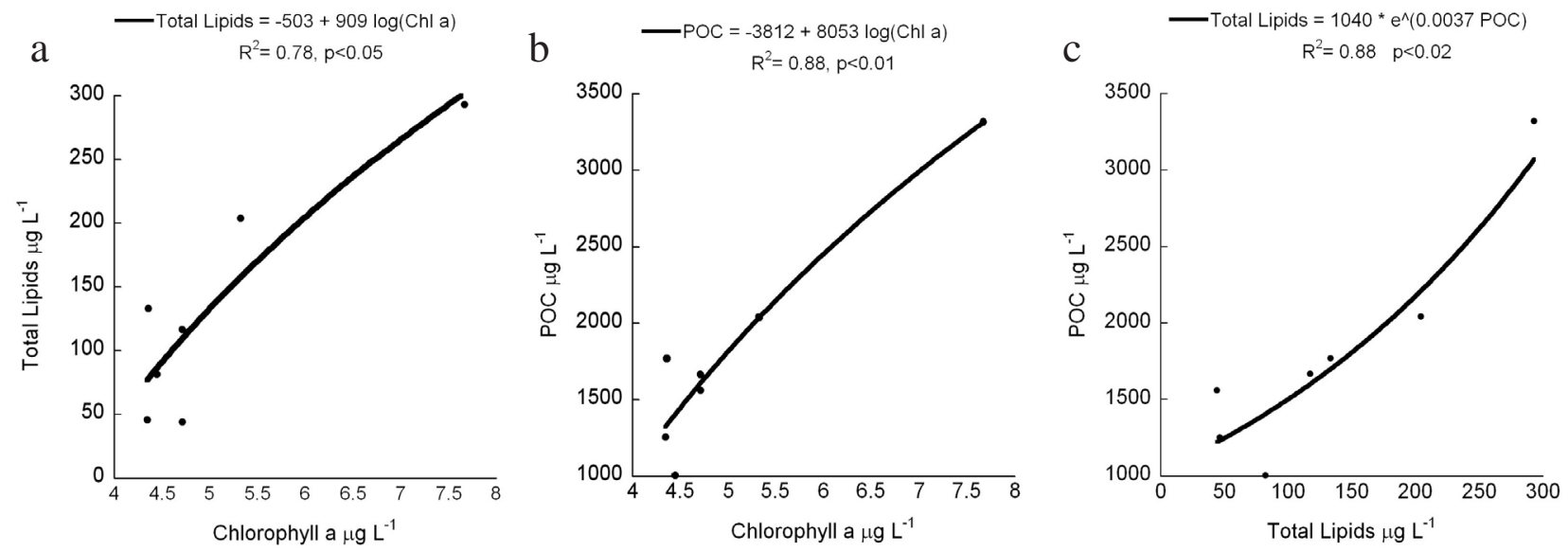

FIG. 3. - Relationship between total lipids and chlorophyll $a(\mathrm{Chl} a)(\mathrm{a})$, particulate organic carbon (POC) and Chl $a$ (b), and particulate organic carbon (POC) and total lipids (c) during the 48-hour cycle at Chipana Bay. Equation and significance are shown for each curve fit.

almost $3500 \mu \mathrm{g}$ POC L L $\mathrm{L}^{-1}$ and $400 \mu \mathrm{g}$ PON L-1. Before and after that peak, values were around $1200-2000 \mu \mathrm{g}$ $\mathrm{L}^{-1}$ for POC and $130-250 \mu \mathrm{g} \mathrm{L} \mathrm{L}^{-1}$ for PON. C/N values were similar during the short time cycle in these shoreline waters, ranging between 6.9 and 8.3.

The closest relationship between these biochemical variables was found to be the POC-chlorophyll $a$ relationship (Fig. 3b). Total lipids also showed a good relationship with chlorophyll $a$ (Fig. 3a), but the relationship between total lipids and POC was higher (Fig. 3c).

\section{Phytoplankton concentration}

The phytoplankton community was clearly dominated by dinoflagellates, especially those of the Protoceratium reticulatum species (Table 2, Fig. 4). The maximum concentration of $P$. reticulatum $(383520$ cell $\mathrm{L}^{-1}$ ) coincided with the maximum peaks of chlorophyll $a$, total lipids, particulate organic carbon and particulate nitrogen (14:00 on 14 February 2007). In fact, the concentration was more than four times higher than seven hours earlier (7:00) and dropped again seven hours later (21:00). During the rest of the cycle concentrations were fairly constant, rising in the last sampling (7:00 on 16 February, Table 2). Other dinoflagellate species maintained constant concentrations during the cycle, but the number of cysts or resting stages showed a peak in coincidence with the Protoceratium reticu- latum peak at 7:00 on 14 February (the concentration was almost three times higher than at the first sampling point, Table 2). Cyst concentration remained constant after the above-mentioned peak. Diatoms were less abundant than dinoflagellates, and in particular small diatoms $(<50 \mu \mathrm{m}$ length) dominated during this short time cycle. Maximum concentrations of both groups were present during the 14:00 peak on 14 February. There were also diatom chains, but the concentration was negligible compared to the free cell diatoms (60300 chains $\mathrm{L}^{-1}$, data not shown in Table 2). Ciliates also showed a higher concentration during the peak at 14:00 on 14 February.

The total number of cells during this cycle ranged between $133 \times 10^{3}$ cells $\mathrm{L}^{-1}$ and $505 \times 10^{3}$ cells $\mathrm{L}^{-1}$. The highest proportion was Protoceratium reticulatum cells (\%), especially in the more concentrated peak (Fig. 4). Twenty-four hours after this high concentration peak (14:00 on 15 February) the proportion of diatoms increased, but was again displaced by $P$. reticulatum (although the total concentration of this dinoflagellate was lower than in previous samplings). Also, the proportion of cysts increased noticeably 24 hours after the highest concentration peak (Fig. 4).

Figure 5 shows the relationship between the total lipid concentration and the total cell concentration per litre. Again, the two parameters had a significant relationship: the variance explained by the equation is almost $70 \%$, with a low error probability $(\mathrm{p}<0.01)$. 


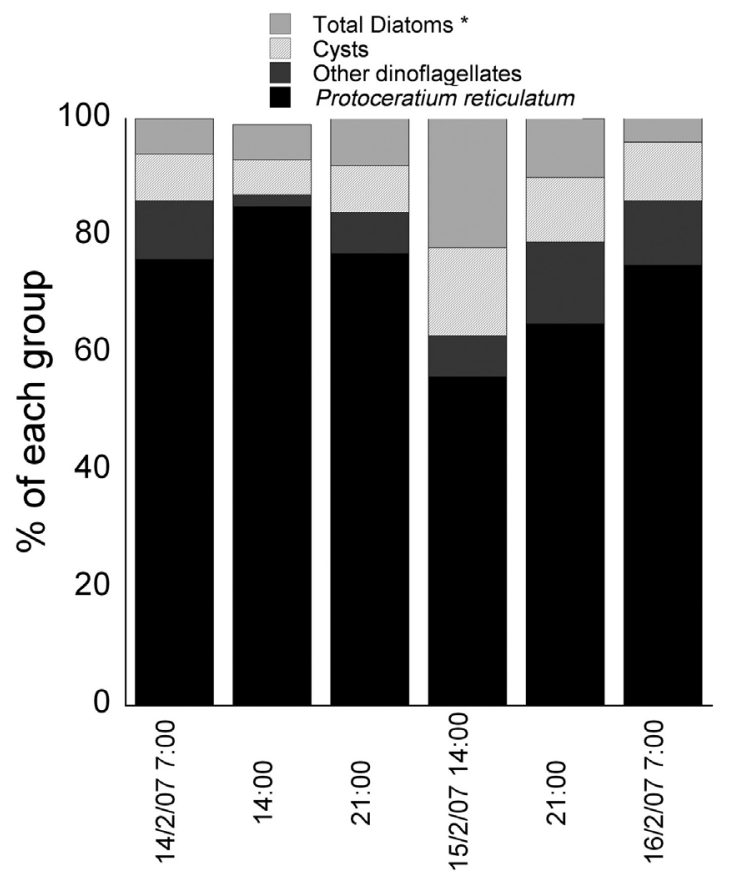

FIG. 4. - Phytoplankton group proportion (\% of the total) during the 48-hour cycle at Chipana Bay. * Indicates the sum of diatoms, which can be seen in detail by size in Table 2 .

\section{Fatty acids}

Saturated Fatty Acids (SAFA) were the most abundant fatty acids in the present short time cycle (Table 3). Especially C18:0 and C16:0 represented stable proportions during the studied period, $24,9 \%-28,3 \%$

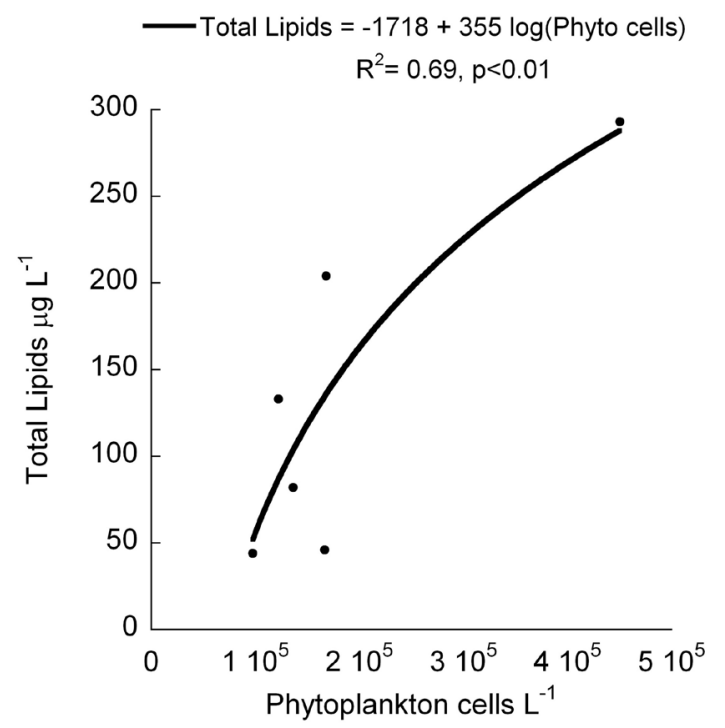

FIG. 5. - Total lipid ( $\mu \mathrm{g} \mathrm{L}^{-1}$ ) and total cell concentration (cells $\mathrm{L}^{-1}$ ) relationship during the 48-hour cycle at Chipana Bay. Equation and significance are shown.

for $\mathrm{C} 18$ and $21,9 \%-25 \%$ for $\mathrm{C} 16$. The $\mathrm{C} 14: 0$ was also abundant, and C12:0, C13:0, C15:0, C17:0 or C20:0 were also present during the whole cycle. Medium- to long-chained SAFA were also present in this cycle (i.e. C22:0 and C24:0), especially C24:0, which had high proportions particularly in the peak concentration (14:00 on 14 February, 1,6\%).

Monounsaturated fatty acid (MUFA) showed low concentrations during the cycle (Table 3 ). The most

TABLE 3. - Fatty acid composition (\% of the total fatty acids) in the near shore intensive cycle at Chipana Bay (from 14 to 16 February 2007).

\begin{tabular}{|c|c|c|c|c|c|c|}
\hline Fatty Acid & $\begin{array}{c}140207 \text { 7a.m. } \\
\mathrm{N}=3 \\
\%\end{array}$ & $\begin{array}{c}140207 \text { 14p.m. } \\
\mathrm{N}=2 \\
\%\end{array}$ & $\begin{array}{c}140207 \text { 21p.m. } \\
\mathrm{N}=3 \\
\%\end{array}$ & $\begin{array}{c}150207 \text { 7a.m. } \\
\mathrm{N}=3 \\
\%\end{array}$ & $\begin{array}{c}15020721 \mathrm{p} . \mathrm{m} . \\
\mathrm{N}=3 \\
\%\end{array}$ & $\begin{array}{c}160207 \text { 7a.m } \\
\mathrm{N}=3 \\
\%\end{array}$ \\
\hline $\mathrm{C} 12: 0$ & 1.1 & 1.0 & 1.0 & 0.1 & 0.8 & 0.9 \\
\hline C13:0 & 0.5 & 1.0 & 1.3 & 0.6 & 1.0 & 0.8 \\
\hline C14:0 & 8.4 & 3.4 & 6.4 & 5.8 & 9.2 & 4.8 \\
\hline C15:0 & 0.7 & 0.5 & 0.5 & 0.6 & 0.7 & 0.6 \\
\hline C16:0 & 22.0 & 24.3 & 24.0 & 25.0 & 23.1 & 23.2 \\
\hline $\mathrm{C} 16: 1(\mathrm{n}-7)$ & 2.4 & 2.7 & 2.3 & 3.1 & 8.8 & 4.1 \\
\hline $\mathrm{C} 17: 0$ & 1.0 & 0.9 & 0.9 & 0.8 & 1.0 & 0.9 \\
\hline C18:0 & 25.5 & 24.9 & 25.4 & 28.3 & 28.0 & 28.1 \\
\hline C18:1 (n-9) & 1.8 & 6.1 & 7.0 & 5.7 & 4.0 & 5.8 \\
\hline $\mathrm{C} 18: 1(\mathrm{n}-7)$ & 0.9 & 1.2 & 1.8 & 2.1 & 1.6 & 1.8 \\
\hline $\mathrm{C} 18: 2(\mathrm{n}-6)$ & 0.7 & 0.4 & 1.7 & 0.2 & 0.4 & 0.3 \\
\hline $\mathrm{C} 18: 3(\mathrm{n}-3)$ & 1.3 & 3.5 & 2.3 & 1.8 & 0.8 & 0.7 \\
\hline $\mathrm{C} 18: 4(\mathrm{n}-3)$ & 11.4 & 10.5 & 8.4 & 8.5 & 5.1 & 9.9 \\
\hline $\mathrm{C} 20: 0$ & 1.2 & 0.5 & 0.8 & 0.7 & 0.5 & 0.6 \\
\hline $\mathrm{C} 20: 1$ (n-9) & 0.8 & 0.0 & 0.0 & 0.6 & 0.0 & 1.0 \\
\hline $\mathrm{C} 20: 4(\mathrm{n}-6)$ & 2.9 & 1.8 & 0.5 & 0.6 & 1.6 & 1.9 \\
\hline $\mathrm{C} 20: 5(\mathrm{n}-3)$ & 9.2 & 6.0 & 7.6 & 6.4 & 5.2 & 5.7 \\
\hline $\mathrm{C} 22: 0$ & 0.3 & 1.0 & 0.4 & 0.6 & 0.3 & 1.0 \\
\hline $\mathrm{C} 22: 6(\mathrm{n}-3)$ & 5.9 & 5.3 & 3.9 & 4.2 & 3.4 & 3.9 \\
\hline $\mathrm{C} 24: 0$ & 1.5 & 1.6 & 0.6 & 0.8 & 1.3 & 1.2 \\
\hline OTHERS & 0.5 & 3.1 & 2.1 & 3.6 & 3.0 & 2.9 \\
\hline SAFA & 62.1 & 59.3 & 61.4 & 63.3 & 66.1 & 62.0 \\
\hline MUFA & 6.0 & 10.0 & 11.1 & 11.4 & 14.4 & 12.7 \\
\hline PUFA & 31.4 & 27.6 & 24.5 & 21.7 & 16.6 & 22.4 \\
\hline Total & 100.0 & 100.0 & 100.0 & 100.0 & 100.0 & 100.0 \\
\hline
\end{tabular}


abundant was 18:1(n-9), though 16:1(n-9) (considered a good marker of diatom cells, Reuss and Poulsen, 2002 and Daalsgard et al., 2003) also showed moderate values during the cycle. Other MUFA were greater than $5 \%$ during the short time cycle [e.g. 18:1(n-7) and 20:1(n-9)].

Polyunsaturated fatty acids (PUFA) showed higher concentrations than MUFA in this near-coast short time cycle (Table 3 ). Especially most abundant were $18: 4(n-3)$, ranging from $5.1 \%$ to $11.4 \%, 20: 5(n-3)$, ranging from $5.2 \%$ to $9.2 \%$, and $22: 6(n-3)$, ranging from $1.4 \%$ to $3.3 \%$. Other PUFA were less concentrated, although present in moderate values [e.g. 18:3(n-3) and $20: 4(n-6)]$.

The relationships between the proportion (\%) of fatty acid biomarkers considered mainly of dinoflagellate origin (18:4(n-3), 22:6(n-3) and 20:5(n-3) (Reuss and Poulsen, 2002 and Daalsgard et al., 2003) and the proportion (\%) of dinoflagellates within the cycle are presented in Fig. 6a,b. The biomarkers, 18:4(n-3) and 22:6(n-3), showed a good exponential relationship (Fig. 6a,b), but the third one, 20:5(n-3), showed a non-significant relationship $\left(\mathrm{R}^{2}=0.15, \mathrm{p}>0.05\right.$; data not shown). Most of the dinoflagellates were represented by Protoceratium reticulatum during the studied cycle (Fig. 4). The relationship between the percentage of $P$. reticulatum and the percentage of 18:4(n-3) was significant $[\% 18: 4(n-3)=-80.42+47.57 \log (\%$ Pro toceratium), $\mathrm{R}^{2}=0.68$ and $\mathrm{p}<0.05$, figure not shown]. The relationship between the percentage of $P$. reticulatum and the percentage of 22:6(n-3) was also significant, although it explained less variance $[\% 22: 6(n-3)=$ $-26.62+16.57 \log (\%$ Protoceratium $), \mathrm{R}^{2}=0.41$ and $\mathrm{p}<0.05$, figure not shown] .

\section{DISCUSSION}

These are, to our knowledge, the first results in which fatty acid proportions and other biological parameters of the potentially toxic dinoflagellate Protoceratium reticulatum are shown taking into account three important considerations: coastal upwelling waters, near bottom sampling and high-frequency field monitoring.

Our results show up to three times more lipids and cells per litre and almost double the concentration of chlorophyll $a$ within a very short period of time (seven hours, Fig. 1, 2 and Table 2). It has been shown that changes in water masses may also change the concentration of suspended particles in nearbottom water layers (Fegley et al., 1992; Rossi and Gili, 2007). This short-term variation in seston availability may have effects on individual and population characteristics of benthic suspension feeders (Fegley et al., 1992). In the above-mentioned studies, the concentration of biological and biochemical parameters such as cell concentration, chlorophyll $a$, POC and proteins may change within a few hours, doubling or even tripling the original concentration due to envi-
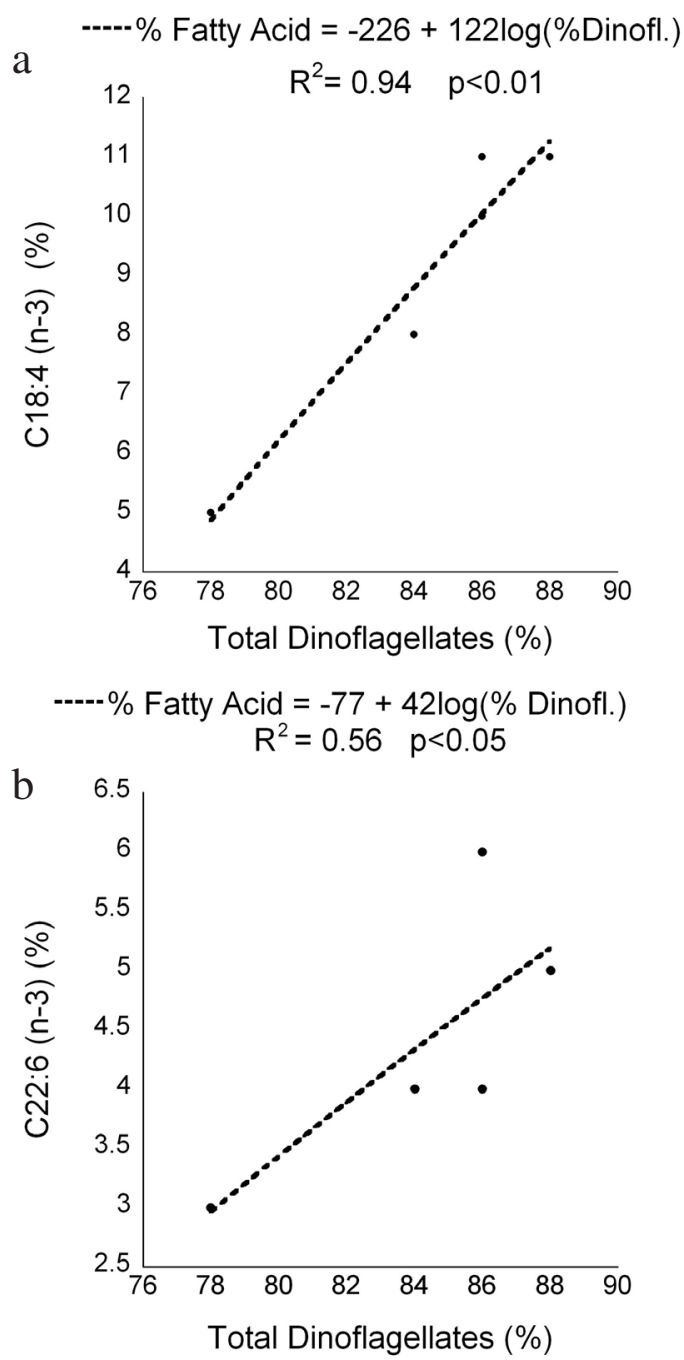

FIG. 6. - Relationship between C18:4(n-3) fatty acid (\%) and total dinoflagellates (\%)(a), and C22:6(n-3) fatty acid (\%) and total dinoflagellates (\%) (b) during the 48-hour cycle at Chipana Bay. Equation and significance are shown for each curve fit.

ronmental factors (currents, wave action, etc.). This is not surprising, because near-bottom water layers and coastal environments are highly dynamic, and their variability may show changes that can be compared with seasonal and inter-annual variability (Rossi and Gili, 2005). In our case, abrupt topography and coastline geometry might be major causes for high hydrodynamism near the coast (Palma et al., 2006), which may explain sudden shifts in algal concentration in a short time interval. In the study zone, it is presumed that particle retention can be high because of the dense algal canopy near the sampling station (Villegas et al., 2008). It has been shown that the hydro-dynamism of this area is partly responsible for fish larval retention (Palma et al., 2006) and phytoplankton concentration (Herrera and Escribano, 2006) near the coast. We suggest that high particle retention in this and similar coastal areas affected by the Hum- 
boldt Current system is partly responsible for high food availability, for pelagic and benthic feeders.

\section{Fatty acids in the $P$. reticulatum bloom}

The $P$. reticulatum bloom had significant amounts of fatty acid markers considered of dinoflagellate origin, 18:0, 18:4(n-3), 20:5(n-3), and 22:6(n-3) (see Reuss and Poulsen, 2002; Daalsgard et al., 2003 for reviews) during the short time cycle. The fatty acid proportions shown by this species and the other dinoflagellates (both groups represent more than $80 \%$ of the cells during the cycle except at one specific point in time) agree with most of the previous records made in the field and with laboratory experiments (Hallegraeff et al., 1991; Mansour et al., 1999; Broglio et al., 2003). Furthermore, the relationships during the red tide progress between 18:4(n-3) and 22:6(n-3) and dinoflagellates in general and the $P$. reticulatum cell concentration in particular were also significant (Fig. 7a,b and equations displayed in the results). Interestingly, when diatoms were abundant (but not dominant), 16:1(n-7) (a marker that can be considered of diatom origin, see Reuss and Poulsen, 2002; Daalsgard et al., 2003) was high, which may be the reason for the significant relationship between this marker and the diatom cell concentration. The diatom markers were less abundant, but still present. One possibility is that diatom cell concentration has a high proportion of lipids than other cell groups (Claustre et al., 1990; Fahl and Kattner, 1993; Kuwata et al., 1993): the low proportion of cells compared with dinoflagellates (and especially with P.reticulatum) did not completely mask the diatom lipids. When different trophic links are considered in a web structure, this information must be considered carefully (Dalsgaard and St. John, 2004). In fact, fatty acid markers can be accumulated by higher trophic levels and not be present in high proportions in the seston analyzed (Klungsøyr et al., 1989; St. John and Lund, 1996, Rossi et al., 2008).

The saturated fatty acids (SAFA) predominate in this Protoceratium reticulatum proliferation. Apart from the dominance of 16:0 and 18:0 SAFA, some fatty acid markers that can be considered of bacterial origin were at least present or showed a significant proportion in the present red tide progress $(13: 0,15: 0$ or 17:0, Budge et al., 2001). This is not surprising, because dinoflagellate blooms are associated with high bacterial biomass in coastal environments (Gasol et al., 2005), and because the offshore system holds an anoxic zone below 50-70 m depth that hosts a high concentration of bacteria (Arntz et al., 2006). The point that remains unclear is why we did not find fatty acids that may be considered to be of macroalgal origin (Daalsgard et al., 2003). In this area, the dominance of two macroalgal species is especially relevant (Macrocystis integriflora and Lessonia trabeculata, Villegas et al., 2008), and the POC found in our results could partly come from macroalgal detritus. Even if a pre-filtering treatment has been made, it has been shown in previous studies that macroalgal detritus in coastal near-bottom water layers can form a high proportion of the overall POC concentration (Rossi and Gili, 2005). This macroalgal material has a poor food value for benthic organisms compared with primary production from microalgae (Grémare et al., 1988).

\section{Food availability associated with a red tide}

The present results fit very well with previous studies in which there is a combination of parameters to describe phytoplankton or seston availability for the trophic steps (i.e. chlorophyll $a$, total lipids or POC and PON values) in this upwelling system (Vargas et al., 2006) or in other environments considered highly productive (Fahl and Kattner, 1993; Reuss and Poulsen, 2002). Compared with more oligotrophic systems, the minimum values found in the present short time cycle (4-5 $\mu \mathrm{g} \mathrm{Chl} \mathrm{a} \mathrm{L}^{-1}, 50-100 \mu \mathrm{g}$ Lipids L $\mathrm{L}^{-1}, 1000 \mu \mathrm{g}$ POC $\mathrm{L}^{-1}$ or $150 \mu \mathrm{g} \mathrm{PON} \mathrm{L}^{-1}$ ) are considerably higher than the maximum values in the higher production peaks of the seasons of the former systems considered most productive (Rossi and Gili, 2007).

It is accepted that high lipid contents in the seston of near-bottom water layers may be a good indicator of food availability for benthic suspension feeders (Grémare et al., 1997). The biochemical variables (Chl $a$, lipids and POC) have a good relationship with each other (Fig. 3), and the total lipid concentration fits very well with the cell concentration of the water column (Fig. 5, a very similar result to that found by Reuss and Poulsen, 2002 in a bloom progress in west Greenland). This suggests that most of the lipids (and, in this case, chlorophyll a and POC/PON) come from the cells of the red tide. The low $\mathrm{C} / \mathrm{N}$ values $(\sim 7-8)$ also suggest that most of the particulate carbon comes from the phytoplankton (Atkinson and Smith, 1983). This can be considered a high amount of available food for benthic suspension feeders, which in this shallow coastal system could be the major controllers of the phytoplankton cell concentration (Cloern, 1982).

In the present study some active filter feeders of the area could be benefiting from its high energetic value (Hitchcock, 1982). The filter feeding behaviour of two abundant bivalves of the zone (Argopecten purpuratus and Aulacomya ater, Villegas et al., 2008) has been observed to be very different in the presence of this Protoceratium reticulatum red tide. A. purpuratus (a pectinid) actively filtered, having apparently no inhibition during the algal bloom, whilst $A$. ater (a mytilid) did not show active filtration during the event (Fiorillo and Rossi personal observation). Li et $a l$. , (2002) showed no difference in respiration rates between clams and mussels when experimentally exposed to high concentrations of the toxic dinoflagellate Alexandrium tamarese, but the absorption efficiency clearly decreased in mussels in comparison with the other bivalve group. It seems that some bivalves may be especially sensitive to red tides (Nielsen and Strom- 
grem, 1991), but others may be more tolerant (Li et al., 2002). In our short time cycle, the cell concentration (dominated by P.reticulatum) can be considered moderate if compared with other algal proliferations (Garcés et al., 1999; Cembella et al., 2002). In this particular area, up to $2.5 \times 10^{6}$ cells $\mathrm{L}^{-1}$ have been found off coastal areas (mainly diatoms, Herrera and Escribano, 2006), so it is possible that, even taking into account the potential toxicity of the species, the values found here did not completely inhibit the benthic suspension feeder activity. In that case, the potential food availability would be high, and would partially explain the richness of the benthic fauna in this upwelling zone (Arntz et al., 2006).

\section{Potential impact of the red tide}

Protoceratium reticulatum is a noxious dinoflagellate identified in various countries (Satake et al., 1997; Samdal et al., 2004). This is the first time that it has been officially described in this coastal region near the fisheries management area. In this study, no toxicity test was made, so we can only refer to other studies made in similar oceanographic conditions. Previous studies showed that low concentrations of Protoceratium reticulatum $\left(20-30 \times 10^{3}\right.$ cells $\left.\mathrm{L}^{-1}\right)$ in shallow waters induced the accumulation of yessotoxins in blue and greenshell mussels (MacKenzie et al., 2002). Our results showed a cell concentration one order of magnitude higher in shallow waters in comparison with the above-mentioned observations. Furthermore, it has been shown that at medium-low temperatures $\left(16-18^{\circ} \mathrm{C}\right)$ and intermediate values of salinity (32), the toxicity of $P$. reticulatum increases (Guerrini et al., 2007). In the study area, near the coast ( 2 miles off the coastal line) surface temperature was $18^{\circ} \mathrm{C}$ and salinity 34 (Aguilera et al., 2009), which are close to the experimental observations made by Guerrini et al., (2007). It can be concluded that, even if some benthic species (e.g. Argopecten purpuratus) may benefit from, or at least not be affected by, this red tide progress in the study area, the artisanal fisheries based on the benthic organisms harvested during this period (summer, in which the harvesting effort is maximum) may be subject to restrictions due to these recurrent algal proliferations.

Most of the Chilean and Peruvian artisanal fisheries are near the coast (Arntz et al., 2006). As red tides become a more frequent phenomenon not only on this coast (Uribe and Espejo, 2003) but all over the world (Masó and Garcés, 2006), the quality and quantity of sea food for human consumption must be monitored, especially in spring and summer, when algal blooms become more extended and frequent, with subsequent impacts for local fisheries. In the present paper we provide no evidence for the toxicity of the red tide (we suggest a potential danger), but we demonstrate that dinoflagellates may have an equivalent lipid content to diatoms in this upwelling system when algal concentrations are similar.

\section{AKNOWLEDGEMENTS}

We are grateful to Mario Villegas (Requiescat in Pacem), Daniel Carstensen and Juërgen Laudien for field support in Chipana and to Enrique Isla, Elisabet Sañé and "el Perra" for logistics. Phytoplankton groups were identified with the help of Claudio FuentesGrunewald and the fatty acid analysis was carried out by Mireia Farrés. We are also grateful for the comments of two anonymous reviews that greatly improved the final version of the manuscript. This study was funded by the EU Project CENSOR (Climate Variability and El Niño Southern Oscillation: Implications for Natural Resources and Management, contract 511071). SR was co-financed by a Beatriu de Pinós Contract (2006 BP-B1 00069) and by a Ramón y Cajal Contract (RyC-2007-01327).

\section{REFERENCES}

Aguilera, V., R. Escribano and L. Herrera. - 2009. High frequency responses of nanoplankton and microplankton to wind-driven upwelling off Northern Chile. J. Mar. Syst., 78: 124-135.

Arntz, W.E., V.A. Gallardo, D. Gutiérrez, E. Isla, L.A. Levin, J. Mendo, C. Neira, G.T. Rowe, J. Tarazona and M. Wolff. 2006. En Niño and similar perturbation effects on the benthos of the Humboldt, California, and Benguela current upwelling ecosystems. Adv. Geosci., 6: 243-265.

Atkinson, M.J. and S.V. Smith. - 1983. C:N:P ratios of benthic marine plants. Limnol. Oceanogr., 28: 568-574.

Barnes, H., and J. Blackstock. - 1973. Estimation of lipids in marine animals tissues: detailed investigation of the sulphophosphovanillin method for "total" lipids. J. Exp. Mar. Biol. Ecol., 12: 103-118.

Broglio, E., S.H. Jónasdóttir, A. Calbet, H.H. Jakobsen and E. Saiz. -2003 . Effect of heterotrophic versus autotrophic food on feeding and reproduction of the calanoid copepod Acartia tonsa: relationship with prey fatty acid composition. Aquat. Micro. Ecol., 31: 267-278.

Budge, S.M., C.C. Parrish, and C.H. McKenzie. - 2001. Fatty acid composition of phytoplankton, settling particulate organic matter and sediments at a sheltered bivalve aquaculture site. Mar. Chem., 2001: 285-303.

Cembella, A.D., M.A. Quilliam, N.I. Lewis, A.G. Bauder, C. Dell'Aversano, K. Thomas, J. Jellet and F. Cusack. -2002 . The toxigenic marine dinoflagellate Alexandrium tamarese as the probable cause of mortality of caged salmon in Nova Scotia. Harm. Algae, 1: 313-325.

Claustre, H., S.A. Poulet, R. Williams, J.C. Marty, S. Coombs, F. Ben Mlih, A.M. Hapette and V. Martin-Jezequel. - 1990. A biochemical investigation of Pheocystis sp bloom in the Irish Sea. J. Mar. Biol. Ass. U. K., 70: 197-207.

Cloern, J.E. - 1982. Does the benthos control phytoplankton biomass in south San Francisco Bay? Mar. Ecol. Progr. Ser., 9: 191-202.

Dalsgaard, J. and M. St. John. - 2004. Fatty acid biomarkers: validation of food web and trophic markers using ${ }^{13} \mathrm{C}$-labeled fatty acids in juvenile sandeel (Ammodytes tobianus). Can. J. Fish. Aquat. Sci., 61: 1671-1680.

Dalsgaard, J., M. St. John, G. Kattner, D. Müller-Navarra and W.Hagen. - 2003. Fatty acid trophic markers in the pelagic marine environment. Adv. Mar. Biol., 46: 225-340.

Escribano, R., G. Danieri, L. Farías, V.A. Gallardo, H.E. González, D. Gutiérrez, C.B. Lange, C.E. Morales, O. Pizarro, M. Ulloa and P. Braun. - 2004. Biological and chemicals consequences of the 1997-1998 El Niño in the Chilean coastal upwelling system: a synthesis. Deep Sea Res. Part II, 51: 2389-2411.

Fabiano, M. and A. Pusceddu. - 1998. Total and hydrolizable particulate organic matter (carbohydrates, proteins and lipids) at a coastal station in Terra Nova Bay (Ross Sea, Antarctica). Pol. Biol., 19: 125-132.

Fahl, K. and G. Kattner. - 1993. Lipid content and fatty acid compo- 
sition of algal communities in sea-ice and water from Weddell Sea (Antarctica). Pol. Biol., 13: 405-409.

Fegley, S.R., B.A. MacDonald and T.R. Jacobsen. - 1992. Shortterm variation in the quantity and quality of seston available to benthic suspension feeders. Est. Coast. Shelf Sci., 34: 393-412.

Fernández-Reiriz, M.J., J.M. Navarro, A.M. Contreras and U. Labarta. -2008 . Trophic interactions between the toxic dinoflagellate Alexandrium catenella and Mytilus chilensis: feeding and digestive behaviour to long-term exposure. Aquat. Tox. 87: 245-251.

Garcés, E., M. Masó and J. Camp. - 1999. A recurrent and localized dinoflagellate bloom in Mediterranean beach. J. Plank. Res., 21: 2373-2391.

Gasol, J.M., E. Garcés and M. Vila. - 2005. Strong small-scale temporal bacterial changes associated with the migrations of bloom-forming dinoflagellates. Harm. Algae, 4: 771-781.

González, H.E., R. Giesecke, C.A. Vargas, M. Pavez, J. Iriarte, P. Santibañez, L. Castro, R. Escribano and F. Pagès. - 2004. Carbon cycling through the pelagic foodweb in the northern Humboldt Current off Chile $\left(23^{\circ}\right.$ S). I.C.E.S. J. Mar. Sci., 61: 572-584.

Grémare, A., A. Marsh and K. Tenore. - 1988. Short-term reproductive responses of Capitella sp. I (Annelida: Polychaeta) fed on different diets. J. Exp. Mar. Biol. Ecol., 123: 147-162.

Grémare, A., J.M. Amouroux, F. Charles, A. Dinet, C. RiauxGobin, J. Baudart, L. Medernach, J.Y. Bodiou, G.Vétion, J.C. Colomines and P. Albert. - 1997. Temporal changes in the biochemical composition and nutritional value of the particulate organic matter available to surface deposit-feeders: a two year study. Mar. Ecol. Progr. Ser., 150: 195-206.

Guerrini, F., P. Ciminiello, C. Dell'Aversano, L. Tartaglione, E. Fattorusso, L. Boni and R. Pistocchi. - 2007. Influence of temperature, salinity and nutrient limitation on yessotoxin production and release by the dinoflagellate Protoceratium reticulatum in batch cultures. Harm. Algae, 6: 707-717.

Hallegraeff, G.M., P.D. Nichols, J.K. Volkman, S.I. Blackburn and D.A. Everitt. - 1991. Pigments, fatty acids, and sterols of the toxic dinoflagellate Gymnodinium catenatum. J. Phycol., 27: 591-599.

Hernández-Miranda, E., A.T. Palma and F.P. Ojeda. - 2003. Larval fish assemblages in nearshore coastal waters off central Chile: temporal and spatial patterns. Est. Coast. Shelf Sci., 56: 1075-1092.

Herrera, L. and R. Escribano. - 2006. Factors structuring the phytoplankton community in the upwelling site off El Loa River in northern Chile. J. Mar. Syst., 61: 13-38.

Hitchcock, G.L. - 1982. A comparative study of the size-dependent organic composition of marine diatoms and dinoflagellates. $J$. Plank. Res., 4: 363-377.

Klungsøyr, J., S. Tilseth, S. Wilhelmsen, S. Falk-Petersen and J.R. Sargent. -1989 . Fatty acid composition as an indicator of food intake in cod larvae Gadus morhua from Lofoten, Northern Norway. Mar. Biol., 102: 183-188.

Kuwata, A., T. Hama and M. Takahashi. - 1993. Ecophysiological characterization of two life forms, resting spores and resting cells, of a marine planktonic diatom, Chaetoceros pseudocurvisetus, formed under nutrient depletion. Mar. Ecol. Progr. Ser., 102: 245-255.

Li, S.C., W.X. Wang and D.P.H. Hsie. - 2002. Effects of toxic dinoflagellate Alexandrium tamarese on the energy budgets and growth of two marine bivalves. Mar. Environ. Res., 53: 145-160.

MacKenzie, L., P. Holland, P. McNabb, V. Beuzenberg, A. Selwood and T. Suzuki. - 2002. Complex toxin profiles in phytoplankton and greenshell mussels (Perna canaliculus), revealed by LCMS/MS analysis. Toxicon, 40: 1321-1330.

Mansour, M.P., J.K. Volkman, A.E. Jackson and S.I. Blackburn. - 1999. The fatty acid and sterol composition of five marine dinoflagellates. J. Phycol., 35: 710-720.

Masó, M. and E. Garcés. - 2006. Harmful microalgae blooms (HAB): problematic conditions that induce them. Mar. Poll. Bull., 53: 620-630.

Nielsen, M.V. and T. Stromgrem. - 1991. Shell growth response of mussels (Mytilus edulis) exposed to toxic microalgae. Mar. Biol., 108: 263-267.

Palma, W., R. Escribano and S.A. Rosales. - 2006. Modelling study and inter-annual variability of circulation in the coastal upwelling site of the El Loa River off northern Chile. Est. Coast. Shelf Sci., 67: 93-107.

Parsons, T.R., Y. Maita and C.M. Lalli. - 1985. Fluorometric determination of Chlorophylls. In: A manual of chemical and biological methods for sea water analysis. Pergamon Press,
Oxford: pp 201-203.

Paz, B., P. Riobó, I. Ramilo and J.M. Franco. - 2007. Yessotoxins profile in strains of Protoceratium reticulatum from Spain and USA. Toxicon, 50: 1-17.

Pitcher, G.C. and D. Calder. - 2000. Harmful algal blooms of the southern Benguela Current: a review and appraisal of monitoring from 1989 to 1997. South Afr. J. Mar. Sci., 22: 255-271.

Quiroga, E., R. Quiñones, M. Palma, J. Sellanes, V.A. Gallardo, D. Gerdes and G. Rowe. - 2005. Biomass size-spectra of macrobenthic communities in the oxygen minimum zone off Chile. Est. Coast. Shelf Sci., 62: 217-231.

Reguera, B., I. Bravo, J. Mariño, M.J. Campos, S. Fraga and A. Carbonell. - 1993. Trends in the occurrence of Dinoiphysis spp in Galician coastal waters. In: T.J. Samyda and Y. Shimizu (eds.) Toxic phytoplankton blooms in the sea, pp. 559-564. Elsevier, Amsterdam.

Reuss, N. and L.K. Poulsen. - 2002. Evaluation of fatty acids as biomarkers for a natural plankton community. A field study of a spring bloom and a post-bloom period off West Greenland. Mar. Biol., 141: 423-434.

Rossi, S. and J.M. Gili. - 2005. Composition and temporal variation of the near-bottom seston in a Mediterranean coastal area. Est. Coast. Shelf Sci., 65: 385-395.

Rossi, S. and J.M. Gili. - 2007. Short-time-scale variability of near bottom seston composition during spring in a warm temperate sea. Hydrobiologia, 557: 373-388.

Rossi, S., M. Youngbluth, C. Jacoby, F. Pagès and X. Garrofé. 2008. Fatty acid composition and trophic links among seston, crustacean zooplankton and the siphonophore Nanomia cara in Georges Basin and Oceanographer Canyon (NW Atlantic). Sci. Mar., 72(2): 403-416.

Ruiz, J., T. Antequera, A.I. Andres, M.J. Petron and E. Muriel. - 2004. Improvement of a solid phase extraction method for analysis of lipid fractions in muscle foods. Anal. Chem. Acta, 520: 201-205

Russell, J.M. and J.P. Werne. - 2007. The use of solid phase extraction columns in fatty acid purification. Org. Geochem., 38: 48-51.

Samdal, I.A., L.J. Naustvoll, P. Olseng, L.R. Briggs and C.O. Miles, 2004. Use of ELISA to identify Protoceratium reticulatum as a source of yessotoxin in Norway. Toxicon, 44: 75-82.

Satake, M., L. MacKenzie and T. Yasumoto. - 1997. Identification of Protoceratium reticulatum as the biogenic origin of yessotoxin. Nat. Tox., 5: 164-167.

Sekiguchi, K., T. Ogata, S. Kaga, M. Yoshida, Y. Fukuyo and M. Kodama. - 2001. Accumulation of paralytic shellfish toxins in the scallop Patinopecten yessoensis caused by the dinoflagellate Alexandrium catenella in Otsichi Bay, Iwate Prefecture, northern Pacifis coast of Japan. Fish. Sci., 67: 1157-1162.

St. John, M.A. and T. Lund. - 1996. Lipid biomarkers: linking the utilization of frontal plankton biomass to enhanced condition of juvenile North Sea cod. Mar. Ecol. Progr. Ser. 131: 75-85.

Taylor, C.D. and B.L. Howes. - 1994. Effect of sampling frequency on measurements of seasonal primary production and oxygen status in near-shore coastal ecosystems. Mar. Ecol. Progr. Ser. 108: 193-203

Thatje, S., O. Heilmayer and J. Laudien. - 2008. Climate variability and El Niño Southern Oscillation: implications for natural coastal resources and management. Helg. Mar. Res., 62(suppl 1): S5-S14.

Uribe, P. and R.T. Espejo. - 2003. Effect of associated bacteria on the growth and toxicity of Alexandrium catenella. Appl. Environ. Microb., 69: 659-662.

Utermöhl, M. - 1958. Zur vervolkommung der qualitativen Phytoplankton metodik. Mitt. Intern. Verein. Limnol., 9: 1-38.

Vargas, C.A., R. Escribano and S. Poulet. - 2006. Phytoplankton food quality determines time windows for successful zooplankton reproductive pulses. Ecology, 87: 2992-2999.

Villegas, M.J., J. Laudien, W. Sielfeld and W.E. Arntz. - 2008. Macrocystis integriflora and Lessonia trabeculata (Laminares; Phaeophyceae) kelp habitat structures and associated macrobenthic community off northern Chile. Helg. Mar. Res., 62(1): 33-43

Zingone, A. and H.O. Enevoldsen. - 2000. The diversity of harmful algal blooms: a challenge for science and management. Oceanogr. Coast. Manag., 43: 725-748.

Scient. ed.: A. Kuwata.

Received April 6, 2009. Accepted January 14, 2010.

Published online June 29, 2010. 